\title{
Pembinaan Karakter Kajian Suroh Al-Furqon
}

\author{
Tatta Herawati Daulae ${ }^{1}$
}

Email: tattaherawatidaulae@gmail.com

\begin{abstract}
Al-Qur'an is the word of God in the form of miracles, passed down to the Prophet Muhammad, through the angel Gabriel who read it into worship. AlQur'an is the first source in the teachings of Islam and is the main guide for every Muslim. In the Qur'an Surah Al-Furqon verses 63-77 outlined some of the good qualities that are the basis for character development, namely; humble heart, not repay bad behavior with the same bad, do night prayers, feel afraid of the punishment of hellfire, keep away from redundant and miserly behavior, avoid all forms of polytheism, do not commit acts that can eliminate the lives of others, do not commit adultery, repent, always maintain faith and do good deeds, do not give false testimony, do not follow useless or useless work, listen and receive good advice, pay attention to family safety and happiness, and be patient.

Keywords: character, Al-Qur'an
\end{abstract}

\begin{abstract}
Abstrak
Al-Qur'an adalah firman Allah yang berupa mukzijat, diturunkan kepada Nabi Muhammad saw, melalui malaikat Jibril yang mebacanya menjadi ibadah. AlQur'an adalah sumber pertama dalam ajaran Islam dan menjadi pedoman utama bagi setiap muslim. Di dalam Al-Qur'an Surah Al-Furqon ayat 63-77 diuraikan beberapa sifat yang baik yang menjadi dasar dalam pembinaan karakter, yaitu ; merendah hati, tidak mebalas perilaku buruk dengan keburukan yang sama, melakukan shalat malam, merasa takut terhadap azab api neraka, menjauhkan dari perilaku mubazir dan kikir, menghindar dari segala bentuk syirik, tidak melakukan perbuatan yang bisa menghilangkan nyawa orang lain, tidak berbuat zina, bertaubat, selalu memelihara iman dan beramal saleh, tidak memberi kesaksian palsu, tidak mengikuti pekerjaan siasia atau tidak bermanfaat, mendengar dan menerima nasihat baik, memperhatikan keselamatan dan kebahagiaan keluarga, serta bersabar.
\end{abstract}

\section{Kata kunci: karakter, Al-Qur'an}

\section{A. Pendahuluan}

Era milenial mempunyai dampak yang sangat besar bagi manusia, terjadi pergeseran dalam seluruh aspek kehidupan manusia, hal ini disebabkan kemajuan sains dan teknologi, sehingga melahirkan situasi baru, makin maju sains dan teknologi, makin cepat perkembangan

\footnotetext{
${ }^{1}$ Dosen Institut Agama Islam Negeri Padangsidimpuan
} 
perubahan. Maka dalam situasi saat ini, pembinaan karakter dalam diri manusia penting untuk ditingkatkan, karena karakter itu merupakan perilaku manusia yang bersifat positif dan negatif baik lahiriah maupun batiniah.

Karakter yang baik merupakan nilai-nilai yang harus ditanamkan pada kehidupan manusia, karena akan dapat menentukan derajat kemanusiaannya dan membedakannya dari makhluk hewani, tanpa memiliki karakter akan kehilangan derajat kemanusiaannya sebagai makhluk Allah yang paling mulia. Maka salah satu pegangan terbaik bagi kehidupan manusia adalah Al-Qur'an, tulisan ini akan menguraikan pembinaan karakter dalam kajian Al-Qur'an Surah Al-Furqon.

\section{B. Pembahasan Karakter}

1. Pengertian Pembinaan Karakter

Pembinaan berasal dari kata bina, yang mendapat imbuhan pe-an, sehingga menjadi kata pembinaan. Pembinaan adalah usaha, tindakan dan kegiatan yang dilakukan secara efisien dan efektif untuk memperoleh hasil yang lebih baik. ${ }^{2}$

Pembinaan adalah upaya pendidikan formal maupun non formal yang dilakukan secara sadar, berencana, terarah teratur, dan bertanggung jawab dalam rangka memperkenalkan, menumbuhkan membimbing, dan mengembangkan suatu dasar-dasar kepribadiannya seimbang, utuh dan selaras, pengetahuan dan keterampilan sesuai dengan bakat, kecenderungan/keinginan serta kemampuan-kemampuannya sebagai bekal, untuk selanjutnya atas perkasa sendiri menambah, meningkatkan dan mengembangkan dirinya, sesamanya maupun lingkungannya ke arah tercapainya martabat, mutu dan kemampuan manusiawi yang optimal pribadi yang mandiri. ${ }^{3}$

Secara harfiah, karakter berasal dari bahasa inggris, character yang berarti watak, karakter atau sifat dalam bahasa Indonesia, watak diartikan sebagai sifat batin manusia yang mempengaruhi segenap pikiran dan perbuatannya dan berarti pula tabiat dan budi pekerti. ${ }^{4}$ Pengertian secara khusus karakter adalah nilai-nilai yang khas (nilai kebaikan mau berbuat baik, nyata berkehidupan baik dan berdampak baik terhadap lingkungan) yang terpatri dalam diri dan terwujud dalam perilaku. Karakter secara koheren memancar dari hasil olah pikir, olah hati, olah rasa dan olah karsa seseorang atau sekelompok orang.

\footnotetext{
2 http://www.artikata.com/arti-360090-pembinaan.html, diakses 12 April 2020

3 Simajuntak, Membina dan Mengembangkan Generasi Muda (Bandung: Tarsito, 1990), hlm. 84

${ }^{4}$ Marzuki, Pendidikan Karakter Islam (Jakarta: Bumi Aksara, 2015), hlm. 20
} 
Karakter merupakan ciri khas seseorang yang mengandung nilai, kemampuan, kapasitas moral, ketegaran dalam menghadapi kesulitan dan tantangan. 5

Pendapat lain karakter berasal dari kata yunani "charassein" yang berarti barang atau alat untuk menggores, yang dikemudian hari dipahami sebagai stempel atau cap. Jadi watak itu sebagai sebuah stempel atau cap, sifat-sifat yang melekat pada seseorang. ${ }^{6}$ Marzuki mengemukakan bahwa karakter mulia mencakup pengetahuan tentang kebaikan yang menimbulkan komitmen terhadap kebaikan dan akhirnya benar-benar melakukan kebaikan. Dengan demikian karakter mengacu pada serangkaian pengetahuan, sikap, serta perilaku dan keterampilan. ${ }^{7}$

Ahmad Amin mengemukakan bahwa kehendak (niat) merupakan awal terjadi akhlak (karakter) pada diri seseorang jika kehendak itu diwujudakn dalam bentuk pembiasaan sikap dan perilaku. ${ }^{8}$

Dalam bahasa arab karakter sering disebut dengan istilah akhlak yang oleh Ibn Miskawaih diartikan sebagai: hal linnafs da'iyah min ghair fikrin wa la ruwiyatin. Artinya sifat atau keadaan yang tertanam dalam jiwa yang paling dalam yang selanjutnya lahir batin dengan tanpa memerlukan pemikiran dan pertimbangan. ${ }^{9}$

Karakter berkaitan dengan keseluruhan performance seseorang dalam berinteraksi dengan lingkungannya. Oleh karenanya, dalam karakter terkandung unsur moral, sikap dan perilaku. Seseorang dikatakan berkarakter baik atau buruk, tidak cukup hanya dicermati dari ucapannya. Melalui sikap dan perbuatan riil yang mencerminkan nilai-nilai karakter tertentu, maka karakter seseorang akan dapat diketahui. Karakter akan terbentuk melalui kebiasaan. ${ }^{10}$

Menurut tim pakar jati diri bangsa, karakter dipengaruhi oleh dua faktor. Pertama faktor dalam diri (endogen) yang cenderung tidak dapat diubah. Kedua, faktor luar diri

\footnotetext{
${ }^{5}$ Anas Salahuddin, dkk, Pendidikan Karakter Bebasis Agama dan Budaya Bangsa (Bandung: Pustaka Setia, 2013), hlm. 42

${ }^{6}$ Sutarjo Adisusilo, JR, Pembelajaran Nilai Karakter (Jakarta: Raja Grafindo Persada, 2011), hlm. 76

${ }^{7}$ Suyadi, Strategi Pembelajaran Pendidikan Karakter ( Bandung: Remaja Rosda Karya, 2013), hlm. 5

${ }^{8}$ Suyadi, hlm. 6

${ }^{9}$ Abuddin Nata, Pemikiran Para Tokoh Pendidikan Islam (Jakarta: Raja Grafindo Persada, 2001), hlm. 11)

${ }^{10}$ Eko Handoyo, Model Pendidikan Karakter Berbasis Konserpasi (Semarang: Universitas Negeri Semarang dan Widya Karya, 2010), hlm. 31
} 
(eksogen) yang dapat diubah. Beberapa faktor yang termasuk di dalamnya adalah faktor keluarga, media massa, lingkungan sosial dan sekolah. ${ }^{11}$

Pembinaan karakter dimulai dari individu, karena pada hakikatnya karakter itu bersifat individual, meskipun karakter itu dapat berlaku dalam konteks yang tidak individual. Oleh karenanya, pembinaan karakter dimulai dari gerakan individual yang kemudian diproyeksikan menyebar ke individu-individu lainnya lalu setelah jumlah inividu yang tercerahkan secara karakter, maka dengan sendirinya akan mewarnai masyarakat. Pembinaan karakter selanjutnya dilakukan dalam lingkungan keluarga dan harus dilakukan sedini mungkin sehingga mempengaruhi pertumbuhan dan perkembangan. Melalui pembinaan karakter pada setiap individu dan keluarga akan tercipta peradaban masyarakat yang tenteram dan sejahtera.

2. Landasan Pembinaan Karakter

Di dalam Al-Qur'an dijelaskan tentang dasar pembinaan karakter yaitu surah AlAhzab ayat 21:

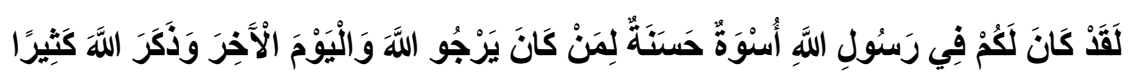

"Sesungguhnya telah ada pada (diri) Rasulullah itu suri teladan yang baik bagimu (yaitu) bagi orang yang mengharap (rahmat) Allah dan (kedatangan) hari kiamat dan dia banyak menyebut Allah."

Surah Al-Mumtahanah ayat 4

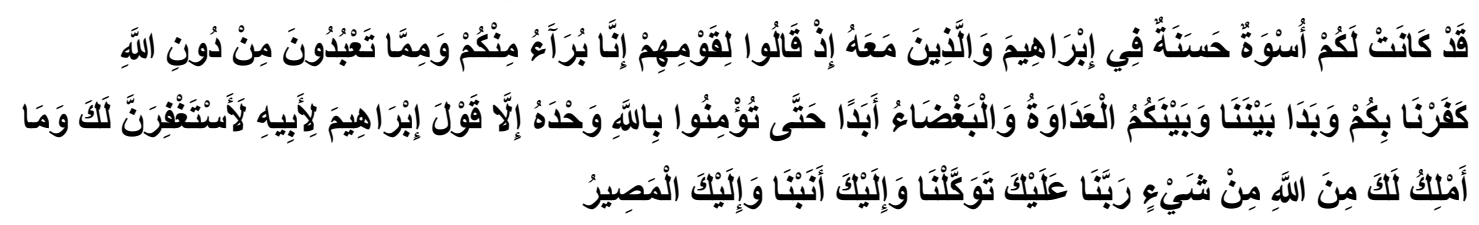

"Sesungguhnya telah ada suri tauladan yang baik bagimu pada Ibrahim dan orang-orang yang bersama dengan dia; ketika mereka berkata kepada kaum mereka: "Sesungguhnya kami berlepas diri daripada kamu dari daripada apa yang kamu sembah selain Allah, kami ingkari (kekafiran)mu dan telah nyata antara kami dan kamu permusuhan dan kebencian buat selama-lamanya sampai kamu beriman kepada Allah saja. Kecuali perkataan Ibrahim kepada bapaknya[1470]: "Sesungguhnya aku akan memohonkan ampunan bagi kamu dan aku tiada dapat menolak sesuatupun dari kamu (siksaan) Allah." (Ibrahim berkata): "Ya Tuhan kami hanya kepada Engkaulah kami bertawakkal dan hanya kepada Engkaulah kami bertaubat dan hanya kepada Engkaulah kami kembali."

${ }^{11}$ Tim Pakar Yayasan Jati Diri Bangsa, Pendidikan Karakter di Sekolah dari Gagasan Ketindakan (Jakarta: Alex Media Komputindo, 2013), hlm. 43-48 
Surah Al-Mumtahanah ayat 6

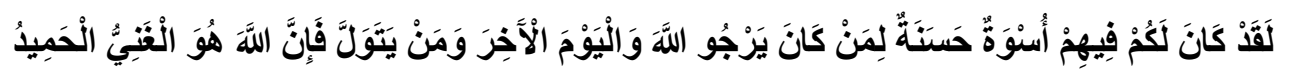

"Sesungguhnya pada mereka itu (Ibrahim dan umatnya) ada teladan yang baik bagimu; (yaitu) bagi orang-orang yang mengharap (pahala) Allah dan (keselamatan pada) Hari Kemudian. Dan barangsiapa yang berpaling, maka sesungguhnya Allah Dia-lah yang Maha kaya lagi Maha Terpuji.”

Pada ayat di atas, Allah menunjuk Nabi Muhammad saw dan Nabi Ibrahim sebagai orang yang diteladani, karena kedua figur ini telah memberikan contoh teladan yang baik kepada umatnya. Seperti mengesakan Allah dengan melarang menyebah patung, ini merupakan ajaran tauhid yang disampaikan kepada umat mereka. Kemudian mereka menyampaikan ajaran Islam dengan cara menyerahkan diri hanya kepada Allah dan sekaligus memohon pertolongan dan mengharap kepada-Nya.

Pada sisi lain banyak sifat-sifat terpuji yang ditunjukkan oleh kedua Nabi Allah tersebut seperti berkorban, penyayang, murah hati dan lain sebagainya.

Kemudian secara konstitusional karakter sudah terermin dari misi pembangunan nasional sebagai misi pertama dari delapan misi guna mewujudkan visi pembangunan nasional, sebagaimana tercantum dalam rencana pembangunan jangka panjang nasional tahun 2005-2025 yaitu terwujudnya karakter bangsa yang tangguh, kompetitif, berakhlak mulia, dan bermoral berdasarkan pancasila yang dicirikan dengan watak dan perilaku manusia dan masyarakat Indonesia yang beragam, beriman dan bertaqwa pada Tuhan Yang Maha Esa, berbudi luhur, bertoleran, bergotong-royong, berjiwa patriotic, berkembang dinamis dan berorientasi IPTEKS. ${ }^{12}$

Sejalan dengan itu dalam Undang-Undang Nomor 20 Tahun 2003 Tentang Sistem Pendidikan Nasional pada pasal 3 disebutkan bahwa:

Pendidikan Nasional berfungsi mengembangkan kemampuan dan membentuk karakter serta peradaban bangsa yang bermartabat dalam rangka mencerdaskan kehidupan bangsa. Pendidikan Nasional bertujuan untuk berkembangnya potensi peserta didik agar menjadi manusia yang beriman, bertaqwa kepada Tuhan Yang Maha Esa,

${ }^{12}$ Zubaeidi, Desain Pendidikan Karakter (Jakarta: Perenada, 2011), hlm. 7 
berakhlah mulia, sehat, berilmu, cakap, kreatif, mandiri, dan menjadi warga Negara yang demokratis serta bertanggung jawab. ${ }^{13}$

\section{Pembinaan Karakter Kajian Surah Al-Furqon}

Suroh Al-Furqon ayat 63-77.

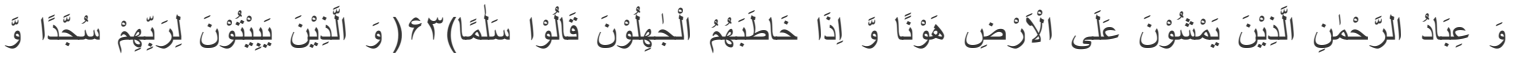

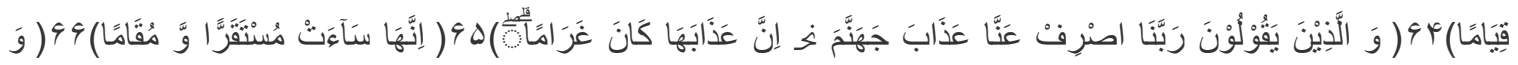

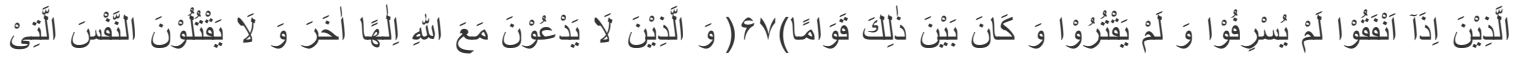

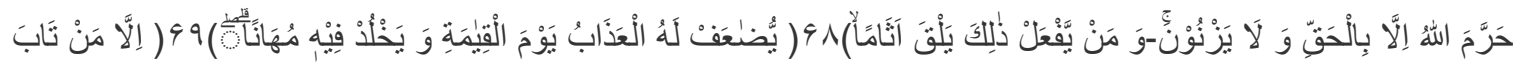

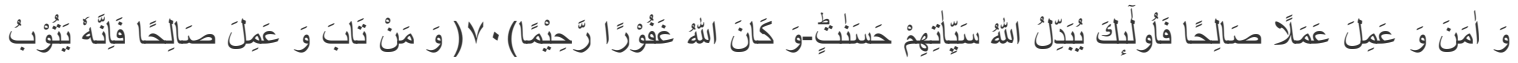

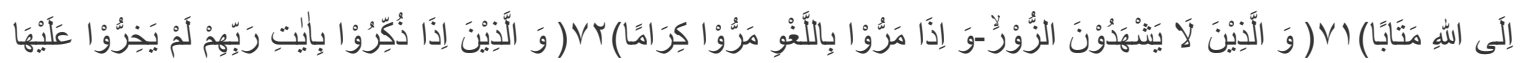

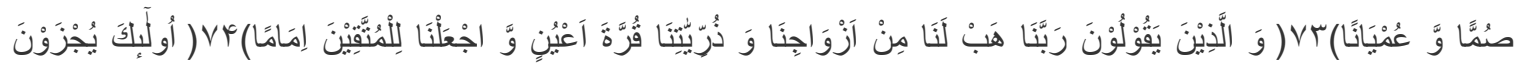

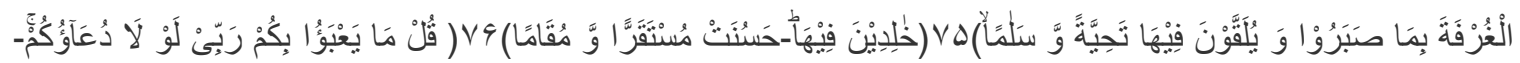

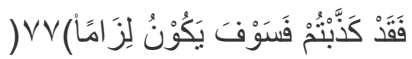

63. dan hamba-hamba Tuhan yang Maha Penyayang itu (ialah) orang-orang yang berjalan di atas bumi dengan rendah hati dan apabila orang-orang jahil menyapa mereka, mereka mengucapkan kata-kata (yang mengandung) keselamatan.

64. dan orang yang melalui malam hari dengan bersujud dan berdiri untuk Tuhan mereka[1072].

65. dan orang-orang yang berkata: "Ya Tuhan Kami, jauhkan azab Jahannam dari Kami, Sesungguhnya azabnya itu adalah kebinasaan yang kekal".

66. Sesungguhnya Jahannam itu seburuk-buruk tempat menetap dan tempat kediaman.

67. dan orang-orang yang apabila membelanjakan (harta), mereka tidak berlebihan, dan tidak (pula) kikir, dan adalah (pembelanjaan itu) di tengah-tengah antara yang demikian. 68. dan orang-orang yang tidak menyembah Tuhan yang lain beserta Allah dan tidak membunuh jiwa yang diharamkan Allah (membunuhnya) kecuali dengan (alasan) yang benar, dan tidak berzina, barang siapa yang melakukan yang demikian itu, niscaya Dia mendapat (pembalasan) dosa(nya),

69. (yakni) akan dilipat gandakan azab untuknya pada hari kiamat dan Dia akan kekal dalam azab itu, dalam Keadaan terhina,

70. kecuali orang-orang yang bertaubat, beriman dan mengerjakan amal saleh; Maka itu kejahatan mereka diganti Allah dengan kebajikan. dan adalah Allah Maha Pengampun lagi Maha Penyayang. 
71. dan orang-orang yang bertaubat dan mengerjakan amal saleh, Maka Sesungguhnya Dia bertaubat kepada Allah dengan taubat yang sebenar-benarnya.

72. dan orang-orang yang tidak memberikan persaksian palsu, dan apabila mereka bertemu dengan (orang-orang) yang mengerjakan perbuatan-perbuatan yang tidak berfaedah, mereka lalui (saja) dengan menjaga kehormatan dirinya.

73. dan orang-orang yang apabila diberi peringatan dengan ayat- ayat Tuhan mereka, mereka tidaklah menghadapinya sebagai orang- orang yang tuli dan buta.

74. dan orang orang yang berkata: "Ya Tuhan Kami, anugrahkanlah kepada Kami isteriisteri Kami dan keturunan Kami sebagai penyenang hati (Kami), dan Jadikanlah Kami imam bagi orang-orang yang bertakwa.

75. mereka Itulah orang yang dibalasi dengan martabat yang Tinggi (dalam syurga) karena kesabaran mereka dan mereka disambut dengan penghormatan dan Ucapan selamat di dalamnya,

76. mereka kekal di dalamnya. syurga itu Sebaik-baik tempat menetap dan tempat kediaman.

77. Katakanlah (kepada orang-orang musyrik): "Tuhanku tidak mengindahkan kamu, melainkan kalau ada ibadatmu. (Tetapi bagaimana kamu beribadat kepada-Nya), Padahal kamu sungguh telah mendustakan-Nya? karena itu kelak (azab) pasti (menimpamu)". ${ }^{14}$

Dari Suroh Al-Furqon di atas terdapat beberapa pembinaan karakter untuk menjadikan manusia yang memiliki karakter yang baik, yaitu:

1. Merendah diri

Karakter yang baik itu dimulai dari hati, dilihat dari ayat 63. Karena ayat itu menjelaskan karakter pertama ialah merendahkan hati atau tawadu' bila berjalan.

Bila berjalan ia tidak bersikap sombong dan angkuh, tetapi berjalan wajar dengan langkah yang tegap dan teratur. ${ }^{15}$

Dalam tafsir Jalalain disebutkan yaitu orang-orang yang berjalan di atas bumi dengan rendah diri. Sedang di dalam tafsir Al-Maragi dijelaskan bahwa bila berjalan

${ }^{14}$ Qs. Al-Furqoni: 63-77.

15 Tim Pelaksana Pentashihan Mushaf Al-Qur'an, Al-Qur’an Bayan ( Jakarta: Bayan Qur'an; 2012 ), hlm. 
tenang dan sopan, tidak menghentak-hentakkan kaki maupun terompahnya dengan congkak dan sombong.

Ibnu Abbas mengatakan, orang-orang mu'min yang berjalan itu ialah ulama yamg bersikap lemah lembut, sopan dan menjaga kehormatannya.

Mengenai gambaran nabi saw. dikatakan bahwa apabila tergelincir beliau mengangkat kakinya dengan kuat beliau melangkah dengan sedikit condong ke depan, berjalan dengan halus dan tenang, langkahnya lebar, dan apabila berjalan seakan dia sedang berada di jalan yang menurun. Yakni, beliau mengangkat kakinya dnegan cepat dan melebarkan langkahnya, berbeda dengan orang berjalan menyombongkan diri. Semua itu beliau lakukan dengan halus dan pasti tanpa tergesa-gesa. Karena itu dikatakan, seakan beliau berjalan di jalan yang menurun. Demikian dikemukakan oleh Al-Qadi 'Iyad di dalam Asy-Syifa'.

Mereka tidak sombong, tidak ingin meninggikan diri, tidak pula ingin mengadakan kerusakan di muka bumi.

“Orang-orang yang berjalan di atas muka bumi dengan rendah hati," yaitu dengan ketentraman dan kewibawaan, tanpa otoriter dan kesombongan, seperti dalam Surah Luqman ayat 18: "Dan janganlah kamu berjalan di muka bumi dengan angkuh". Mereka adalah orang-orang yang berjalan tanpa kesombongan. Tanpa keangkuhan, tanpa kekerasan, dan tanpa kekejaman. Yang dimaksud bukanlah mereka berjalan seperti orang sakit yang dibuat-buat dan sekedar ingin dilihat orang lain. Akan tetapi yang dimaksud dengan rendah hati disini adalah ketentraman dan kewibawaan.

Sesungguhnya orang-orang yang beriman adalah kaum yang merendahkan diri. Pendengaran, penglihatan, dan anggota tubuh mereka sederhana, sampai orang-orang jahil menyangka bahwa mereka adalah orang-orang sakit, padahal diantara mereka tidak ada yang terkena penyakit. 16

2. Tidak membalas perilaku buruk dengan keburukan yang sama

Pada ayat 63 dijelaskan, bahwa salah satu pembinaan karakter yang baik mampu melakukan yang baik, sekalipun orang berlaku buruk padanya. Hal ini menunjukkan

${ }^{16}$ Abdullah bin Muhammad Alu Syaikh, Penerjemah M. Abdul Ghoffar, Tafsir Ibnu Katsir Jilid 6 (Jakarta: Pustaka Imam Asy-Syafii, 2013), hlm. 473 
kebersihan hati, karena ia dapat mengendalikan emosi. Bila orang menghina dan mencemoohkannya, tidak membalas dengan ucapan yang serupa.

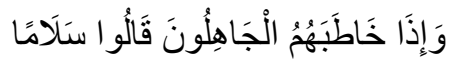

Jika mereka disapa dengan orang-orang bodoh dengan perkataan yang buruk, mereka tidak membalasnya dengan perkataan serupa, tetapi memberi maaf dan hanya memberikan perkataan yang baik. Rasulullah jika mendapat perlakuan yang kasar dari orang yang jahil, maka hal itu membuat beliau semakin penyantun.

Hasan Al-Basri mengatakan, mereka adalah para penyantun yang tidak jahil. Jika mereka dijahili, maka mereka bersikap penyantun dan tidak jahil. Ini adalah sikap mereka di siang hari. Bagaimana dengan sikap mereka di malam hari ? sungguh malam yang paling baik; mereka meneguhkan keimanan dan mengalirkan air mata memohon kepada Allah agar dimerdekakan dari perbudakan. ${ }^{17}$

"Dan apabila orang-rang jahil menyapa mereka, mereka mengucapkan kata-kata (yang mengandung) keselamatan." Jika orang-orang jahil mengumpat mereka dengan ucapan yang buruk, mereka tidak membalasnya dengan ucapan yang buruk pula, akan tetapi mereka memaafkan, membiarkan dan tidak membalas melainkan dengan perkataan yang baik. Sebagaimana Rasulullah tidak membalas perbuatan jahil mereka melainkan dengan kesabaran dan lemah lembut. Mujahid berkata "Yakni mereka mengucapakan kebenaran." 18

3. Melakukan Shalat Malam

Ayat 64 menjelaskan bahwa bagian dari pembinaan karakter yang baik itu adalah melakukan shalat malam. Salah satu dari hikmah shalat malam adalah untuk menguatkan jiwa, sebagaimana disebutkan dalam surah Al-Muzzammil ayat 1-5, yaitu untuk membangun kemampuan jiwa untuk menerima perkataan-perkataan yang berat, ciri yang ketiga ini tetap berkaitan dengan ciri yang pertama dan kedua. Mereka bangun dari tidur untuk mengerjakan shalat malam bermunajat dengan tuhannya memohon ampunannya dan mengharapakan karunia dan ridhanya.

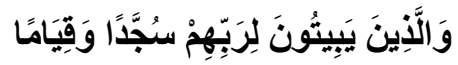

\footnotetext{
${ }_{17}$ Ahmad Mustafa Al-Maragi, Terjemah Tafsir Al-Maragi (Semarang: Thaha Putra, 1993), hlm. 68

${ }^{18}$ Abdullah bin Muhammad Alu Syaikh, hlm. 473
} 
Orang-orang yang bermalam dengan bersujud dan berdiri untuk beribadah kepada Allah, yakni mereka mneghidupkan seluruh malam atau sebahagiannya dengan shalat. Diungkapkannya ibadah dengan bangun malam secara khusus terhindar dari berlaku riya. Ibnu Abbas mengatakan, barangsiapa melakukan shalat dua rakaat atau lebih setelah shalat isya, berarti dia telah bermalam dengan bangun bersujud kepada Allah. Seperti firman Allah

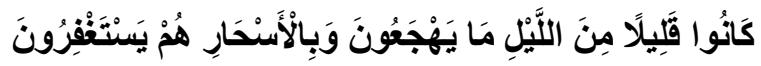

"Di dunia mereka sedikit sekali tidur diwaktu malam. Dan selalu memohonkan ampunan diwaktu pagi sebelum fajar." (Adz-Dzaariyat ayat 17: 18)

4. Merasa takut terhadap adzab api neraka

Ayat 65 menjelaskan bahwa dalam pembinaan karakter yang baik itu ialah selalu bermohon agar dijauhkan dari adzab api neraka. Hal ini terjadi karena dorongan rasa takut yang kuat terhadap siksa api neraka itu, sehingga membuat mereka selalu berdo'a. hal ini juga bisa didorong oleh rasa keyakinan yang kuat terhadap adanya siksa neraka itu. Mereka yakin dan percaya akan hari akhirat, hari hisab serta adanya surga dan neraka. Oleh karena itu ia selalu bermohon kepada tuhannya agar diselamatkan dari siksaan neraka yang amat dahsyat dan hebat.

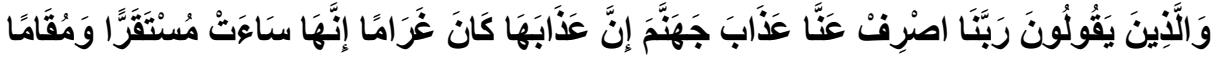

Orang-orang yang memohon kepada Allah agar dia memalingkan mereka dari adzab jahannam dan penderitaannya yang sangat keras. Disini Allah memuji mereka, bahwa sekalipun mereka telah bergaul baik dengan sesama makhluk dan bersungguhsungguh beribadah kepada Al-Khaliq, namun mereka senantiasa takut kepada adzabnya dan berdo'a agar dia memalingkan mereka darinya, tidak menumpukan harapan pada amal salah yang mereka lakukan. Kemudian Allah mengemukakan dua alasan mengapa mereka mengajukan permohonan yaitu ; karena adzab jahannam itu adalah kebinasaan yang kekal dan kerugian yang pasti; karena jahannam itu adalah seburuk-buruk tempat tinggal dan tempat menetap. ${ }^{19}$

5. Menjauhkan dari perilaku mubazir dan kikir

Ayat 67 menjelaskan bahwa bagian dari pembinaan karakter yang baik itu tidak mubazir dalam berbelanja dan tidak pula kikir. Mereka tidak boros dalam membelanjakan

\footnotetext{
${ }^{19}$ Ahmad Mustafa Al-Maragi, hlm. 70
} 
harta bendanya, namun juga tidak kikir sehingga membawa kepada kerusakan dan tidak pula bersikap loba dan tamak karena yakin bahwa kedua sifat itu tidak diridhai Allah. Dia berada ditengah kedua sifat tersebut yaitu tetap menafkahkan harta bendanya tanpa pemborosan atau tidak menahan harta itu untuk ditumpuk. ${ }^{20}$

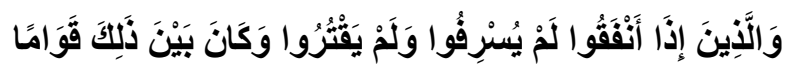

Orang-orang yang tidak berlaku mubazir di dalam mengeluarkan nafkah, maka tidak mengeluarkannya lebih dari kebutuhan, tidak pula kikir terhadap diri mereka dan keluarga mereka, tetapi mereka mengeluarkannya secara adil dan pertengahan dan sebaik-baik perkara adalah yang paling pertengahan.

Dikatakan pula, jika sesorang memberikan kepada dirinya segala apa yang diingininya dan tidak mencegahnya, maka ia akan rindu kepada segala kebatilan, dan dia akan menuntunnya kepada dosa serta celaan dengan kemanisan sementara yang ia serukan kepadanya. $^{21}$

6. Menghindar dari segala bentuk syirik

Syirik itu ada berbentuk keyakinan dan dalam ibadah (perkataan dan perbuatan), mereka tidak pernah mempersekutukan Allah dengan apapun juga dalam segala tindak tanduknya, karena dia meyakini bahwa menyeleweng dari paham tauhid akan membawa kepada kemurkaan Allah.

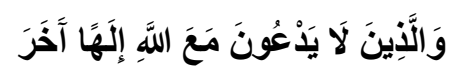

Orang-orang yang tidak menyembah tuhan lain di samping Allah sehingga menyekutukannya dengan-Nya dalam beribadah, tetapai mereka memurnikan ibadah dan ketaatan kepada-Nya semata.

7. Tidak melakukan perbuatan yang bisa menghilangkan nyawa orang lain

Perbuatan yang bisa menghilangkan nyawa orang lain adalah menunjukkan hilangnya rasa belas kasihan dari hati pelakunya dan tumbuhnya emosi yang berlebihan. Dia tidak pernah melakukan pembunuhan karena itu perbuatan keji dan menimbulkan dosa yang amat besar yang akan dibalas tuhan nanti dengan siksaan yang pedih dan menghinakan.

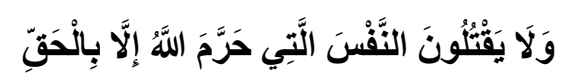

\footnotetext{
${ }^{20}$ Al-Qur'an Bayan, hlm. 360

${ }^{21}$ Ahmad Al-Mustafa Al-Maragi, hlm. 72
} 
Mereka tidak membunuh jiwa orang karena sebab apa pun, kecuali sebab yang haq yang menghilangkan keharaman dan keterpeliharaannya, seperti setelah beriman, berzina setelah bersuami-isteri, dan membunuh jiwa orang secara tidak haq. ${ }^{22}$

8. Tidak berbuat zina

Perbuatan zina ini menunjukkan kehilangan kemampuanm mengendalikan dorongan hawa nafsunya. Jadi orang yang memiliki karakter yang bik itu orang yang mampu mengendalikan hawa nafsu buruknya. Mereka tidak pernah melakukan perzinaan karena perbuatan keji itu adalah dosa yang amat besar yang akan dibalas tuhan nanti dengan siksaan yang pedih dan menghinakan.

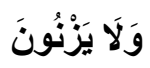

Dan tidak berzina; yakni tidak melakukan persetubuhan yang diharamkan oleh Allah. Al-Bukhari, Muslim dan Tirmizi meriwayatkan dari Ibnu Mas’ud yang artinya “Saya bertanya kepada Rasulullah saw, 'Dosa apakah yang paling besar?' beliau menjawab, 'Kamu menjadikan sekutu bagi Allah, sedangkan Dia telah menciptakanmu'. Saya bertanya, 'Kemudian apa lagi?' Beliau menjawab, 'Kamu membunuh anakmu karena takut jika dia makan bersamamu'. Saya bertanya lagi, 'Kemudian apa?' Beliau menjawab, 'Kamu berzina dengan isteri tetanggamu'."

9. Bertaubat, selalu memelihara iman dan beramal shaleh

Salah satu ciri karakter yang baik ialah orang yang segera bertaubat apabila terlanjur berbuat dosa. Sebagaimana disebutkan dalam Surah Ali Imron ayat 135 yang artinya "Dan (juga) orang-orang yang apabila mengerjakan perbuatan keji atau menganiaya diri sendiri, mereka ingat akan Allah, lalu memohon ampun terhadap dosadosa mereka dan siapa lagi yang dapat mengampuni dosa selain dari pada Allah? Dan mereka tidak meneruskan perbuatan kejinya itu, sedang mereka mengetahui.”

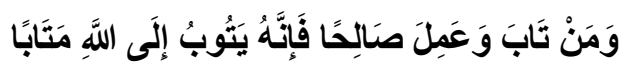

Akan tetapi, siapa saja meninggalkan dosa-dosa di atas disertai dengan beriman dan beramal shaleh maka Allah menghapus segala kemaksiatannya yang telah lalu dengan menerima taubatnya dan mengokohkannya untuk menjalankan ketaatan dimasamasa datang. Barangsiapa bertaubat dari segala kemaksiatan yang telah dilakukannya, menyesali kedurhakaan yang terlanjur dilakukan dan mensucikan dirinya dengan berbuat

${ }^{22}$ Ahmad Al-Mustafa Al-Maragi, hlm. 72 
amal shaleh, maka sesungguhnya dia telah bertaubat kepada Allah dengan sebenar-benar taubat yang diterima oleh Allah, menghapus siksaannya dan memberinya pahala yang banyak. Disamping itu, Allah akan menerangi hatinya dengan cahaya dari sisinya yang menunjukinya ke jalan yang lurus, memberinya taufik untuk mengerjakan kebaikan dan menjauhkannya dari bahaya. ${ }^{23}$

10. Tidak memberi kesaksian palsu

Salah satu pembinaan karakter adalah tidak memberi kesaksian palsu, membela orang yang dzalim atau orang yang berbuat kesalahan.

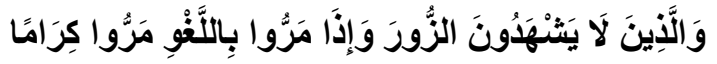

Orang-orang yang tidak memberikan kesaksian palsu, tidak menolong ahli kebatilan dalam melakukan kebatilannya.

Kata Azzuro ada berpendapat syirik, pendapat lain Azzuro adalah dusta, fasik, kufur, main-main dan bathil. Ada pendapat bahwa Azzuro permainan dan lagu, ada mengatakan majlis-majlis keburukan dan kata-kata busuk, Malik berkata, Azzuro adalah meminum khomar, dimana mereka tidak menghadirinya dan tidak menyukainya.

11. Tidak mengikuti pekerjaan sia-sia atau tidak bermanfaat

Mereka adalah orang yang tidak mau ikut mendengarkan omongan yang tidak berguna seperti bergunjing, karena ia menganggap waktunya amal berharga dan dirinya tidak patut berbuat hal-hal yang sia-sia. ${ }^{24}$

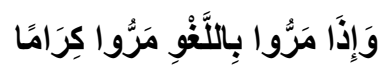

Mereka memuliakan diri mereka dengan tidak mendengarkan perkataan yang tidak berguna dan tidak mengandung kebaikan seperti memperolok Al-Qu'an, mengejek Rasul serta bercakap-cakap tentang perkara yang tidak karuan.

Hal ini dapat dilihat dalam firman Allah surah Al-Qasas ayat 55

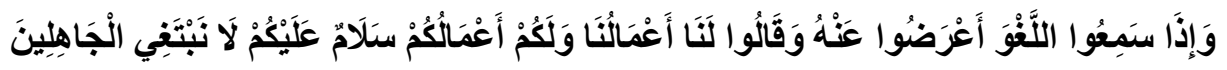

"Dan apabila mereka mendengar perkataan yang tidak bermanfaat, mereka berpaling daripadanya dan mereka berkata: "Bagi kami amal-amal kami dan bagimu amal-amalmu, kesejahteraan atas dirimu, kami tidak ingin bergaul dengan orang-orang jahil."

\footnotetext{
${ }^{23}$ Ahmad Al-Mustafa Al-Maragi, hlm. 75

${ }^{24}$ Abdullah bin Muhammad al-syaikh, hlm. 480
} 
12. Mendengar dan menerima nasihat baik

Mereka meaksanakan semua ajaran Allah baik berupa perintah maupun larangan karena ia meyakini bahwa menaati Allah dan menjauhi larangannya akan membawa kepada kebahagiaan di dunia dan di akhirat.

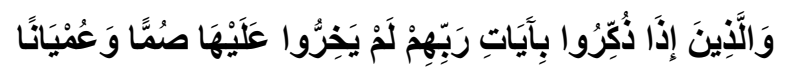

Orang-orang yang apabila disebutkan ayat-ayat tuhannya maka mereka berlutut sambil mendengarkannya dengan telinga dan melihat dengan mata.Mereka apabila diberi peringatan tidak tuli dan buta, artinya mereka tidak tuli kepada kebenaran dan tidak buta tentangnya, mereka kaum yang memahami kebenaran dan dapat mengambil manfaat dari yang didengarnya.

Disini terdapat sindiran terhadap orang-orang kafir dan orang-orang munafik, yang apabila mendengar kalam Allah, maka mereka tidak tersentuh olehnya, tidak pula berpaling dari perbuatannya, malah terus tenggelam dalam kekufuran, kedurhakaan dan kejahilan. Seakan merekan tuli, tidak mendengar, dan buta, tidak melihat. ${ }^{25}$

13. Memperhatikan keselamatan dan kebahagiaan keluarganya

Mereka adalah orang-orang yang senantiasa berdoa kepada Allah agar ia dan keluarganya bahagia, diberi keturunan yang baik dan shaleh, sehingga dapat menjadi contoh teladan bagi generasi selanjutnya, karena ia ingin agama Allah bertambah banyak pengikutnya. ${ }^{26}$

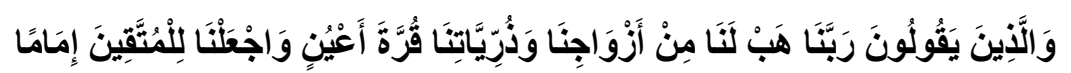

Orang-orang yang memohon kepada Allah agar melahirkan dari mereka keturunan yang taat dan beribadah kepada-Nya semata dan tidak menyekutukan-Nya. Orang-orang yang beriman dengan sebenar-benar iman, apabila melihat keluarganya sama dengannya, taat kepada Allah maka dia akan merasa senang dan gembira, dia mengharapkan mereka dapat berguna baginya di dunia dan di akhirat. Mereka juga memohon agar Allah menjadikan mereka para imam yang diteladani dalam menegakkan agama dengan menganugerahkan ilmu yang luas dan memberi taufik kepada mereka untuk mngerjakan amal shaleh. ${ }^{27}$

\footnotetext{
${ }^{25}$ Ahmad Al-Mustafa Al-Maragi, hlm. 77

${ }^{26}$ Tim Pelaksana Pentashihan Mushaf Al-Qur'an, hlm. 480

${ }^{27}$ Ahmad Al-Mustafa Al-Maragi, hlm. 70
} 
Mereka meminta kepada Allah untuk dikeluarkan dari tulang sulbi mereka, keturunan mereka yang taat dan hanya beribadah kepada-Nya. Ibnu Abbas berkata: yaitu orang beramal ketaatan kepada Allah, hingga menjadi penyejuk mata mereka di dunia dan di akhirat. Ikrimah berkata: mereka tidak dikehendaki menjadi orang yang pandai atau orang tampan, akan tetapi mereka inginkan menjadi orang-orang yang taat. ${ }^{28}$

14. Bersabar

Kesabaran adalah modal besar untuk bisa istiqomah tetap di jalan yang lurus sampai akhir hayat, maka orang yang telah memiliki kesabaran akan mengokohkannya dalam melaksankan ketaatan dan menjauhi larangan yang dapat mengantarkan mereka mendapat kebahagiaan dunia dan akhirat.

Setelah menjelaskan sifat-sifat orang yang baik di atas maka Allah menyebutkan balasan yang diberikan kepada mereka

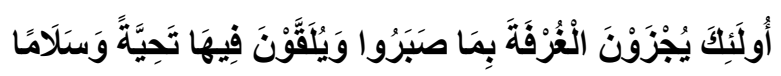

Orang-orang yang memiliki sifat-sifat kesempurnaan dan menyandang akhlak serta adab yang utama diberi balasan berupa kedudukan yang tinggi karena kesabaran mereka dalam menjalankan ketaatan dan menjauhi kemungkaran. Mereka mendapat ucapan selamat dan penghormatan.

\section{Penutup}

Dari uaraian di atas dapat dikemukakan bahwa karakter adalah merupakan perilaku manusia yang bersifat positif dan negative baik lahiriah maupun batiniah. Maka pembinaan perilaku ini merupakan faktor yang terpenting dalam pembinaan manusia, tanpa adanya karakter yang baik akan sulit mendapatkan keselamatan dan kebahagiaan dunia dan akhirat. Dalam hal ini untuk mencapai keselamatan tersebut perlu berpedoman kepada Al-Qur'an khususnya Surah AlFurqan ayat 63-77.

\footnotetext{
${ }^{28}$ Abdullah bin Muhammad Alu Syaikh, 483
} 


\section{DAFTAR PUSTAKA}

Abdullah bin Muhammad Alu Syaikh, Penerjemah M. Abdul Ghoffar, Tafsir Ibnu Katsir Jilid 6, Jakarta: Pustaka Imam Asy-Syafii, 2013.

Abuddin Nata, Pemikiran Para Tokoh Pendidikan Islam, Jakarta: Raja Grafindo Persada, 2001.

Ahmad Mustafa Al-Maragi, Terjemah Tafsir Al-Maragi, Semarang: Thaha Putra, 1993.

Al-Qur'an

Anas Salahuddin, dkk, Pendidikan Karakter Bebasis Agama dan Budaya Bangsa, Bandung: Pustaka Setia, 2013.

Departemen Agama, Kumpulan Undang-Undang Republik Indonesia, Jakarta: Dirjen Pendidikan Islam, 2006.

Eko Handoyo, Model Pendidikan Karakter Berbasis Konserpasi, Semarang: Universitas Negeri Semarang dan Widya Karya, 2010.

http://www.artikata.com/arti-360090-pembinaan.html, diakses 12 April 2020

Marzuki, Pendidikan Karakter Islam, Jakarta: Bumi Aksara, 2015.

Simajuntak, Membina dan Mengembangkan Generasi Muda, Bandung: Tarsito, 1990.

Sutarjo Adisusilo, JR, Pembelajaran Nilai Karakter, Jakarta: Raja Grafindo Persada, 2011.

Suyadi, Strategi Pembelajaran Pendidikan Karakter, Bandung: Remaja Rosda Karya, 2013.

Tim Pakar Yayasan Jati Diri Bangsa, Pendidikan Karakter di Sekolah dari Gagasan Ketindakan, Jakarta: Alex Media Komputindo, 2013.

Tim Pelaksana Pentashihan Mushaf Al-Qur'an, Al-Qur'an Bayan, Jakarta: Bayan Qur'an; 2012.

Zubaeidi, Desain Pendidikan Karakter, Jakarta: Perenada, 2011. 